\title{
Conversational Implicature in English Listening Comprehension
}

\author{
Haiyan Wang \\ College of Foreign Languages, Qingdao University of Science and Technology, Qingdao 266061, China \\ Email: haiyanwang417@163.com
}

\begin{abstract}
Some English learners find it hard to understand a sentence when they are given a piece of listening material although they have a good master of vocabulary and grammatical rules. In order to improve the ability of listening comprehension, it's necessary for English learners to introduce some basic Pragmatics theories. Grice's Conversational Implicature Theory is one of the most important contents of Pragmatics. The theory focuses its attention on the phenomenon of conveying more than what is said. Therefore, the English listeners can and should master the theory of Grice's Conversational Implicature, learn how to infer implicature to guide their learning and lead in such theories in listening comprehension. This thesis attempts to examin the relationship between them and state the roles played by the conversational implicature in listening comprehension.
\end{abstract}

Index Terms - conversational implicature, cooperative principle, listening comprehension

\section{INTRODUCTION}

Sometimes, some English listeners who have a good mastery of vocabulary and grammatical rules may find it hard to understand a sentence when they are given a piece of listening materials, so English listening comprehension concerns the total understanding and application of language a lot besides vocabulary and grammatical structures. Nowadays, although English listeners have changed their learning methods and listening materials in order to improve their listening ability, the listening ability of many English listeners is still deficient. The training of listening still confronts many problems. Hence, how can we efficiently improve the competence of listening comprehension and then cultivate the ability to apply language? As Geoffrey Leech (1983) argues "we cannot really understand the nature of language itself unless we understand pragmatics." (p34) Thus, melting the theory of pragmatics with the listening comprehension is the key step to improve the ability of listening competence.

Pragmatics deals with the study of language in use in different contexts. It didn't appear as an independent branch of linguistics until 1960s and 1970s. As a branch of pragmatics, the theory of conversational implicature experienced a long history and can be traced back to relations with Semiotics and the Theory of Deviation. However, in 1967, the theory of conversational implicature was formally suggested by Herbert Paul Grice, an American linguistic philosopher. From then on, the theory of conversational implicature has been growing quickly with the spreading of pragmatics.

This thesis attempts to state the relationship between the conversational implicature and listening comprehension, find out how Grice's theory of conversational implicature contributes to listening comprehension.

\section{LITERATURE REVIEW OF CONVERSATIONAL IMPLICATURE AND LISTENING COMPREHENSION}

\section{A. What is Conversational Implicature}

Grice's Conversational Implicature Theory is one of the most important contents of Pragmatics. So before mastering this theory, it's necessary to get a general idea of it, including its history, characteristics and contents.

1. The Development of Conversational Implicature

Conversational Implicature: Implicature is a special case of situations in which the perceived meaning extends beyond the literal meaning. Conversational implicature is, therefore, something which is implied in conversation, that is, something which is left implicit in actual language use. (William James Lecture)

The notion of conversational implicature is one of the most important ideas in pragmatics. An implicature is something meant, implied, or suggested distinct from what is said. The term "implicature" is derived from the word "implicate" whose primitive form "implicates" appeared first in Latin around 1530-1540 and whose primitive meaning was "intervene, entangle, involve". Other than the literal meaning, implicature described the implicit meaning or the meaning implied. H. P. Grice, who coined the term "implicature," and classified the phenomenon, developed an influential theory to explain and predict conversational implicature, and describe how they are understood. The "Cooperative Principle" and associated "Maxims" play a central role. Other authors have focused on principles of politeness and communicative efficiency. Herbert Paul Grice was the first one to systematically study the cases in which what a speaker means differs from what the speaker says. Grice's Theory of Conversational Implicature occupied a great part in the linguistic field. 


\section{Grice's Theory of Conversational Implicature}

The Theory of Conversational Implicature was first proposed by Herbert Paul Grice, who is an American linguistic philosopher. H. P. Grice delivered three speeches in his William James lectures at Harvard University in 1967. Among these, the second lecture entitled "Logic and Conversation" came out in 1975 in Syntax and Semantics. There, he presented the theory of "Cooperative Principle" and "Conversational Implicature."

In order to understand comprehensively and thoroughly the purpose and the significance of the proposition of "cooperative principle" and "conversational implicature," we should figure out some ideas of Grice's basic theory about "meaning," which can be divided into natural meaning and non-natural meaning. Natural meaning refers to the meaning of the utterance that can be generally gained by the conversational participants. While the meaning refers to the intended meaning conveyed by the speaker and must be inferred by the receiver in particular contexts. On the base of it, Grice proposed the key ideas of conversational implicature in 1967. If the participants both have the expectation to achieve a successful conversation, they must cooperative with each other, and speak sincerely, sufficiently, relevantly and clearly. To put it another way, they must observe the co-operative principle and the maxims of Quality, Quantity, Relevance and Manner. If someone who participate the conversation flouts the co-operative principle and any of the maxims, he must have intended to do so. And the receiver can infer the speaker's intended meaning in particular contexts. For example:

A: Do you know when John left the pub last night?

B: Eleven o'clock. And he went to Mary's apartment instead of his own.

According to quantity maxim, the contribution should not be more informative than is required. In this way, in the example, as the answer to A, generally, "Eleven o'clock," is enough. However, B adds the later sentence, provides some information that seems not necessary and violates the quatntity maxim. We infer that B wants to tell A that John might have some special relationship with Mary.

\section{Characteristics of Grice's Conversational Implicature}

In Grice's opinion (1975), conversational implicature has five characteristics

1). Cancellability

Conversational implicaures are cancelable or defeasible if we add some other premises to the original ones. For example:

2). Non-detachability

The conversational implicature is attached to the semantic content of what is said, not to the linguistic form used. Therefore it is possible to use a synonym and keep the implicature intact. In order words, the implicature will not be detached, separated from the utterance as a whole, even though the specific words may be changed.

3). Calculability

The conversational implicature of an utterance is different from its literal meaning. There is no direct link between the two. So if it is to succeed as the speaker intends to, there must be ways for the hearer to work it out.

4). Non-conventionality

Conversational implicature is an extra meaning, not inherent in the words used. One cannot find conversational implicature listed in the dictionary. To work out the conversational implicature of an utterance, one needs to know its conversational meaning and the context in which it is used. In other words, a conversational implicature is the adding up of the conventional meaning and the context. The context changes, the implicature will also change.

5). Indeterminacy

An expression with a single meaning can give rise to different implicature on different occasions, and indeed on any one occasion the set of associated implicature may not be exactly determinable.

\section{B. Cooperative Principle}

Cooperative principle is the main branch of Grice's Conversational Implicature Theory. To achieve a successful conversation, participants must be co-operative with each other.

\section{Definition of cooperative principle}

In 1975, the philosopher of language Grice, H. P. pointed out that both the speaker and the addressee have to follow certain pragmatic, syntactic, and semantic rules in order to communicate effectively. They have to co-operative. Grice's Cooperative Principle consists of several maxims that appear very simple, straightforward, and common-sensual at first sight. Grice (1967) observed that conversations, like other human interactions, are governed by a cooperative principle:" make your conversational contribution such as is required, at the stage at which it occurs, by the accepted purpose or direction of the talk exchange in which you are engaged". In other words, the participants should be co-operative, and then their utterances can be relevant to each other. Only in this way can the participants infer what the other one really means in their conversation. And this principle is known as the Cooperative Principle or CP for short.

\section{The four maxims of $\mathrm{CP}$}

Maxims of conversational is Grice's second theory. It is essentially a theory about how people use language. In the theory, he developed the concept of conversational implicature. To Grice, conversational implicature is realized through the four maxims under general principle of conversation.

The cooperative principle is furthered by four maxims, and each has their own regulations respectively: 
The maxim of Quality

(i) Do not say what you believe to be false:

(ii) Do not say that for which you lack adequate evidence.

Obviously, the two conditions are both subjective and make up a general condition that people should be sincere about what they speak out.

The maxim of Quantity

(i) Make your contribution as informative as is required for the current purpose of the exchange;

(ii) Do not make your contribution more informative than is required.

The effect of the maxim is to add to most utterances a pragmatic inference to the effect that the statement presented is the strongest, or more informative, that can made in situation.

The maxim of Relevance

(i) Make your contribution relevant

This maxim is the easiest one, pointing out that participants center about the same topic and avoid asserting something irrelevant.

The maxim of Manner:

(i) Avoid obscurity

(ii) Avoid ambiguity

(iii) Be brief

(iv) Be orderly

The regulations cover many aspects that a standard sentence calls for.

\section{Violation of the Maxims}

There are cases when a speaker fails a maxim or several maxims in conversation in order to convey additional meaning. He appears to infringe the maxims deliberately in appearance, and the speaker will assume that he is still adhering to the maxims at a deeper level, and that he infringes the maxims because he want to draw the hearer's attention, so that the hearer can get particular inferences and understand the particular inferences.

\section{Literature Review of Listening Comprehension}

The definition, nature and importance of listening comprehension will be stated as follows:

\section{The Definition of Listening Comprehension}

ILA (International Listening Association) describes listening as "the process of receiving, constructing meaning from, and responding to spoken and/or nonverbal messages." According to Vandergrift (1999), listening is anything but a passive activity. It is a complex, active process in which the listener must discriminate between sounds, understand vocabulary and grammatical structures, interpret stress and intonation, retain what was gathered in all of the above, and interpret it within the immediate as well as the larger socio-cultural context of the utterance. Coordinating all of this involves a great deal of mental activity of the part of the listener. Rost(2002) defines listening, in its broadest sense, as a process of receiving what the speaker actually says; constructing and representing meaning; negotiating meaning with the speaker and responding; and creating meaning through involvement, imagination and empathy. Although these definitions differ in words, one thing is agreed upon, that is, listening is a complex active process of interpretation in which listeners matches what they hear with what they already know.

\section{The Nature of Listening Comprehension}

On the basis of research work by many scholars, the nature of listening comprehension is presented to us. Just as William Littlewood (1981) states that the nature of listening comprehension means that the learner should be encourage to engage in an active process of listening for meaning, using not only the linguistic clues but also his nonlinguistic knowledge. O'Malley and Chamot state according to their study that listening comprehension is an active and conscious process in which the listener constructs meaning by using cues from contextual information and existing knowledge, while relying upon multiple strategic resources to fulfill the task requirement.

It has been generally agreed that listening comprehension is an active, complex, and constructive process, and listeners play a very active and important role in constructing the meaning of the speaker.

\section{The Importance of Listening Comprehension}

Listening is a vital skill of human communication and contributes much to our understanding of Second Language Acquisition. According to Feyten, more than forty-five percent of our total communication time is spent in listening. Listening has emerged as an important component in the process of second language acquisition.

As Rost (2002) points out, listening is vital in the foreign language classroom because it provides input for the learner. Without understanding input at the right level, learning cannot begin. It is also closely related to the development of spoken language proficiency. Spoken language provides a means of interaction for the learner. Because learners must interact to achieve understanding, access to speakers of the language in essential. Moreover, learners' failure to understand the language they hear is an impetus, not an obstacle. It is now generally recognized that listening comprehension plays a key role in facilitating language learning.

\section{The Current Problems of Listeners}

Although learners give more and more consideration to the listening comprehension ability of language, there still 
exist many barrens which prevent these learners from performing well in the listening process.

\section{Problems of Traditional Learning Method}

Although the listening proficiency directly influences the improvement of the whole level of English, some people still pay little attention to it. In the traditional way of doing listening, people usually first get the exact means of the new words in the listening material, figure out the background, or get some questions to draw our attention to, or simply without these steps, and then plays the tape for themselves to listen and do the exercises. After finishing listening, they just check our answers. Actually they benefit little from such kind of method. Many listening comprehension exercises demands no response until the end of very long stretches of speech, so that when it comes, this response is very largely a test of memory rather than of comprehension. Therefore, some of them become passive listeners because of the lack of participation.

\section{Problems of Listening Materials}

Many listening comprehension exercises used today are still based on formal spoken prose, that's the reason why learners are unable to understand what is being said when she or he first visits a foreign country in spite of years of language study at school. They usually choose the listening materials which are often made up of passages originally composed as written texts recorded onto the tape. This kind of practice does not provide any realistic preparation for the real-life listening.

\section{Failure of Using Conversational Implicature in Listening Comprehension}

Nowadays English learners still benefit little from targeted focus on pragmatic comprehension. They still have no idea on how native English speakers express themselves pragmatically, not just linguistically. When people are given a piece of listening material, they can't focus on both pragmatic and linguistic meaning.

Secondly, besides the above-mentioned Cooperative Principle and Conversational Implicature, people are still not encouraged to have a dip in other linguistic theories such as Principle of Politeness and the Speech Act Theory to help them to do better jobs in inferring the conversational implicature in their listening comprehension.

\section{CONVERSATIONAL IMPLICATURE IN LISTENING COMPREHENSION}

\section{A. Listening Comprehension: A Pragmatic Perspective}

A sentence has its semantic meaning. When the sentence is uttered, it also has its pragmatic meaning.

For example, when listeners hear the sentence "It is hot", they could not know exactly what the speaker really means by decoding its semantic meaning. So what does on earth the speaker mean by uttering "it is hot?" According to different situations, we can get different meanings. (i) When you enter an office and hear your boss say "it is hot," you may infer that your boss's real meaning is to ask you to open the air condition for him or her. (ii) When a boy utters "it's hot" before his mother in the morning, his real meaning is to ask his mother to let him dress fewer. (iii) When a girl is going to eat her soup and hears her mother say "it's hot" on the dinner table, she knows that mother is warning her that she should wait for a moment. So the meaning of the sentence "it's hot" depends on the context it is utter. Thus scholars have noted the importance of investing listening comprehension is from a pragmatics point of view. The native person normally encounters spoken language in a context of situation.

Language philosopher Paul Grice is the first to claim that utterance interpretation is a sort of inferential process, developed to attribute to explain a higher-order speakers meaning. He has designed his Cooperative Principle and maxims. This attribution of meaning is a sort of predictive behavior in which listeners engage to be able to infer all possible meanings. According to Grice, the implicit meaning of an utterance is inferred and the explicit meaning is just decoded. Thus the existence of the implicit content and the inferential process of interpreting it have become the main focus of pragmatics. And the inferential aspect of comprehension has largely been recognized in the listening comprehension study.

\section{B. The Significance of Applying the Conversational Implicature in Listening Comprehension}

Many English learners have difficulty understanding implications of English conversations as there tends to be gap between what is said and what is implied. How to overcome this problem is an important aspect in the improving of English listening comprehension.

For the English major students, one of their difficulties in listening is that they sometimes can understand the meaning of the sentences of the conversation but as far as the questions are concerned, they just cannot figure out the correct answers. When it comes to the passage, some of them will totally be at a loss. Some gradually lose their enthusiasm and motivation and become the passive listeners. At last, some of them even believe that tests cannot improve their listening competence.

For the non-English major English learners, some of them still center around the theoretical discussion on the implicature interpretation. They often focus their attention on the textbooks and the preparation for CET4\&CET6; they think the last mark doesn't stand for their real listening competence.

Based on the problems both the English majors and non-English majors encounter with, we figure out that it's necessary to work out some ways to improve the listening comprehension. For several reasons, the application of the Theory of Conversational Implicature to the improving listening comprehension is an efficient way. Firstly, Grice's theories enable one to explain how native speakers work out the implied meaning of their utterance. Secondly, speakers 
rely heavily on the cooperative principle when interpreting utterances that involve implicature. The speaker assumes that the listeners will be able to work out the implied meaning according to Grice's Maxims. Thirdly, a reliance on the $\mathrm{CP}$ and its Maxims is a strategy that must be learned by non-native speakers if they are to be "discourse competent."

\section{The Role of Conversational Implicature in Listening Comprehension}

Being different and refreshing is what English-speaking people pursue. English speaking people often make use of conversational implicature in conversation for different purposes, such as showing off one's eloquence, avoiding taboos, being polite, etc. After continuous refinement, conversational implicature have perfected to an advanced level and more and more go into conversations. We could take Grice's cooperative principle as the example to do some concrete form analysis in listening comprehension. The violation of the Maxims can give us more inspiration of conversational implicature.

(1) Violation of Quantity Maxim

For example:

A: Do you know when John left the pub last night?

B: Eleven o'clock. And he went to Mary's apartment instead of his own.

According to quantity maxim, the contribution should not be more informative than is required. But from this we can infer that B wants to tell A that John might have some special relationship with Mary.

(2) Violation of Quality Maxim

For example:

A: What will you do if you fail the exam?

B: I'll eat my hat.

Obviously, "hat" cannot be eaten. The words can be inferred that: I will not fail this exam definitely. So words can be expressed with irony and metaphor.

(3) Violation of Relevance Maxim

For example:

A: Whoa! Has your boss gone crazy?

B: Let's go get some coffee.

The context of the conversation is that: when the man is entering the woman's office he notices that she has many works to do. The woman did not answer the man's question according to the maxim of relevance, from the answer we can get that there are reasons that the woman cannot answer the question directly: (i) The woman didn't want to talk about her boss. (ii) Maybe the boss is nearby.

(4) Violation of Manner Maxim

For example

A: Let's get the kids something.

B: Okay, but not I-C-E-C-R-E-A-M

The two people are discussing to buy something for the kids. By violating the maxim of manner, he didn't speak out ice cream directly but spelt it word by word, his propose if very clear, that is, not to make the kids understand what he said.

From the above analysis, it's easy to draw such a conclusion that conversational implicature is of special importance. Such kind of knowledge must be given to learners.

\section{CONCLUSION}

As what have discussed in the above chapters, for many years, people have been trying to improve their listening comprehension abilities. Therefore, the factors influencing listening, no matter the linguistic or non-linguistic factors have been greatly attracting people's attention. Grice's Conversational Implicature theory influences listening comprehension deeply, especially in understanding conversations. In this thesis, it emphasizes on using the Grice's Conversational Implicature Theory to guide the English listening comprehension. Both the non-English learning majors and the English majors can and need to learn the necessary linguistic theories to guide their English listening comprehension, the pragmatic theory can help learners better understand implicated meaning in English listening.

\section{REFERENCES}

[1] Grice. H. P. (1975). Logic and Conversation. In Cole, P\& Morgan, J. (eds.) Syntax and Semantics, vol3. New York: Academic Press.

[2] Grice. H. P. (1967). William James Lecture Series. Boston: Harvard University Press.

[3] Leech.G. (1983). Principles of Pragmatics. London: Longman Group Limited.

[4] Levinson. S.C. (1983). Pragmatics. London: Cambridge University Press.

[5] Vandergrift. L (1999). Facilitating Second Language Listening Comprehension: Acquiring Successful Strategies. ELT Journal 53: $168-176$.

[6] Rost. M. (2002). Teaching and Researching Listening. London, UK: Longman.

[7] William Littlewood. (1981). Communicative Language Teaching. London: Cambridge University Press. 
Haiyan Wang was born in Tai'an, China in 1979. She received her M.A. degree in linguistics from Liao Ning Normal University, China in 2005.

She is currently a lecturer in the School of Foreign Languages, Qingdao University of Science and Technology, Qingdao, China. Her research interests include linguistics and Language Teaching. 